\title{
Critical Issues in Anode Production and Quality to Avoid Anode Performance Problems
}

\author{
Barry A. Sadler* \\ Net Carbon Consulting Pty Ltd \\ Melbourne, Australia
}

Received 23.03.2015, received in revised form 16.04.2015, accepted 19.05.2015

There are a number of key anode quality parameters that must be kept stable and capable in order for the anodes to perform at the standard required by modern cells. If the anode production steps that influence these parameters are not managed well, the resulting sub-standard anodes can impact on the performance of the cell. The link between these properties and anode/cell performance are outlined in this paper.

Keywords: anode production, anode failure, cell performance.

\section{Ключевые проблемы производства анодов \\ и обеспечение их качества}

\author{
Барри А. Сэдлер \\ Net Carbon Consulting Pty Ltd \\ Австралия, Мельбурн
}

Стабильность и функииональные возможности ряда ключевых параметров качества анодов определяют рабочие характеристики анодов, необходимые для соответствия стандартам современных электролизеров. При низком уровне управления технологическими операциями производства анодов, определяющими данные параметры, аноды, не отвечающие требованиям стандартов, влияют на производительность и рабочие характеристики электролизера. В статье рассматривается связь между этими свойствами и рабочими характеристиками анода/электролизера и их значимость. Основное внимание уделяется аспектам качества анодов, не предусматриваемым обычным анализом кернов из обожженных анодов.

Ключевые слова: производство анодов, разрушение анода, поведение электролизера.

(C) Siberian Federal University. All rights reserved

* Corresponding author E-mail address: barry.sadler@bigpond.com.au 


\section{Anode related cell and anode performance issues}

Carbon anodes are an integral component of the electrical circuit within the electrolytic cells that produce aluminium. They participate in a positive way to the process of aluminium metal production by contributing chemical energy, thereby reducing the electrical energy requirements of the electrolytic cell reactions. Carbon anodes can hinder cell operations in a number of ways, some of which are related to anode quality and others that are associated with the way the anodes are used in the cells. The impact of anode problems on cell operations includes:

The physical loss of pieces of carbon into the cell during anode operation

This may be caused by the anode density being too low and variable, which leads to:

- Vertical cracking late in the anode cycle (Pieces of anode can fall off in the cell or during processing of the butts (Fig. 1). Thinner butts make this problem worse ((c) below for further details).

- Thin butts - these can result in flux wash of stubs in the cells and breakthrough of stubs through the working face of the thin anodes; both of these problems increase iron contamination of the aluminium metal.

As butt thickness is one of the constraints on anode life in the cell, there is a direct link between low variation in anode density and increased value, as shown schematically in Fig. 2. It is the low density anodes, and not the average density, that limits anode life, hence if variation in anode density is reduced by removing the low density tail, then anode life in the cell can be extended to reduce production costs. This is one of the key reasons why achieving low variability in density is a prime objective of anode manufacture.

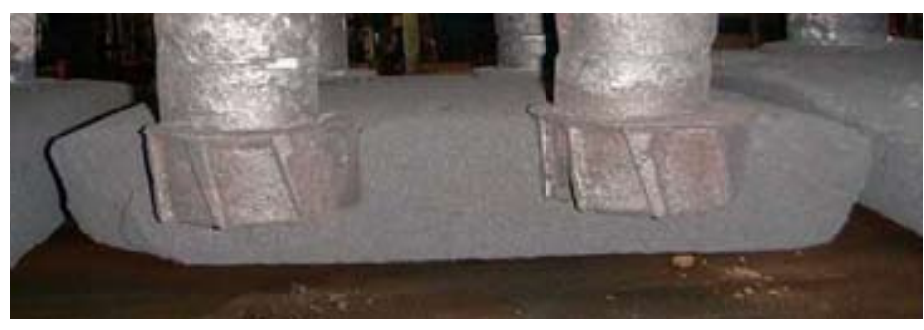

Fig. 1. Late rota cracking of an anode butt, with the end of the butt having fallen into the cell

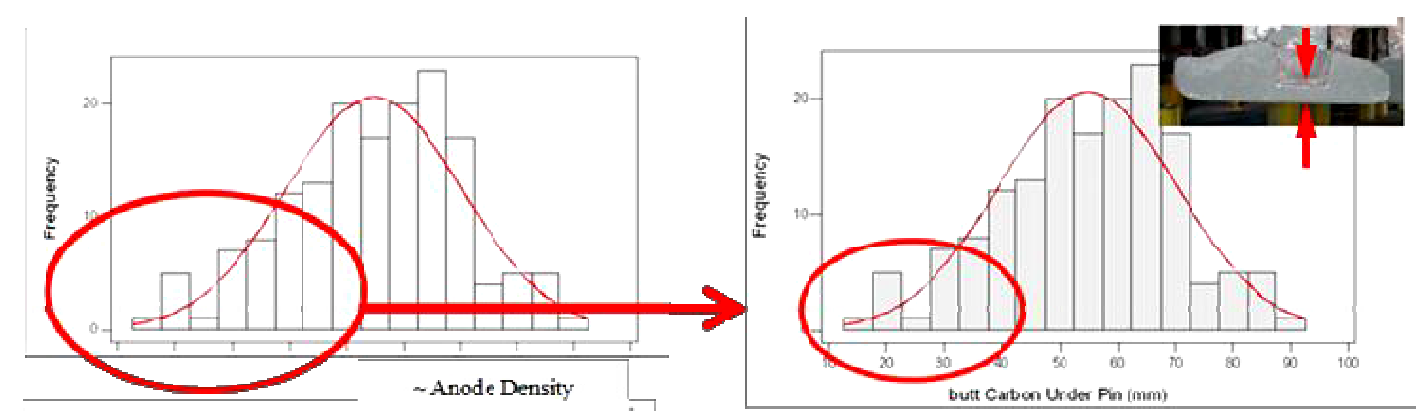

Fig. 2. Schematic illustration of the impact of variation in anode density on the amount of Carbon Under Stub of butts at the end of the anode cycle. It is the low density anodes that give the low Carbon Under Stub results that reduce anode cell life 
Physical loss of small carbon pieces from the anode surface ("dusting”). Dusting results from the selective, sub-surface attack of the anode by air ("Airburn"), Carbon Dioxide ("Carboxy" attack), or selective electrolytic attack in areas on the anode of low current density. Dusting is very damaging to cell operations, reducing current efficiency, increasing power consumption, and increasing hazardous work in the Potlines. It is also a recognised cause of spikes or mushrooms (Fig. 3, 4). Some of the key factors to avoid dusty anodes are to bake the anodes at a sufficiently high temperature, minimise sodium/bath contamination of the anodes from butts recycle, keep permeability at an acceptable level, and cover anodes sufficiently in the cells to avoid airburn.

Anode breakage in the cell. It is usually either from "thermal shock" as the anode is set, or late rota (i.e. anode cycle) cracking. The large carbon pieces that fall into the cell from anode breakage create major problems: they are hazardous to remove, but if not removed, spikes can form if anodes are set on the carbon pieces, and they degrade over time in the cell to form dust.

- Thermal shock is a severe anode problem that has caused major issues at a number of smelters, including the near shutdown of potlines. Thermal shock cracking includes: "corner shedding", "slabbing", or vertical cracking. Corner shedding (Fig. 5) is the classic type of thermal shock failure which has fortunately been markedly reduced by the widespread use of anode slots (these disrupt the stress fields that cause corner shedding) and improved anode formulation (e.g. the adoption of higher "Grain on Sand" aggregates [1] and fabrication practises [2]. "Slabbing" thermal shock (Fig. 6) is when the whole bottom of the anode, or at least a major portion such as the wing of an anode bounded by a slot (Fig. 7) break off after anode setting. Anode slabbing is caused by the propagation of preexisting horizontal cracks in the anode that may have originated during baking or more likely during vibroforming. Vertical thermal shock cracking (Fig. 7) is caused by stresses generated along the length of an anode as it bends slightly like a banana due to thermal expansion upon setting in the cell. The tensile forces generated in the base of the anode can propagate an existing crack, or if severe enough

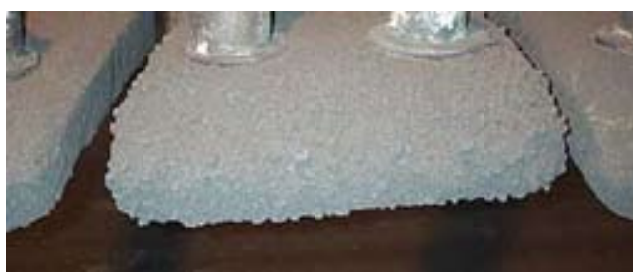

Fig. 3. Typical soft "dusty" butt

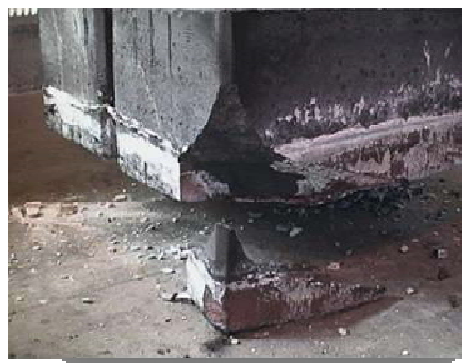

Fig. 5. Corner shedding thermal shock

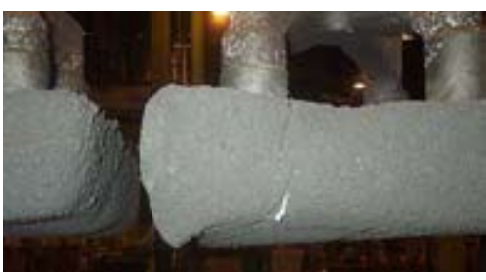

Fig. 4. Spike or mushroom, and late rota anode cracking

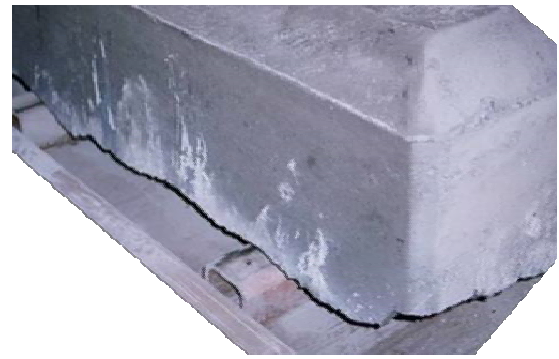

Fig. 6. Slabbing thermal shock 


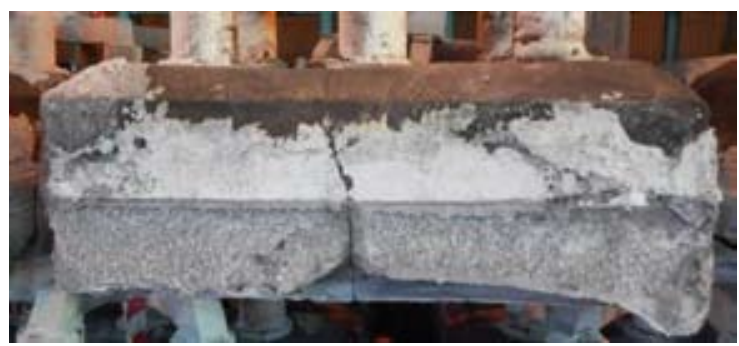

Fig. 7. Vertical and slot "wing" cracking thermal shock

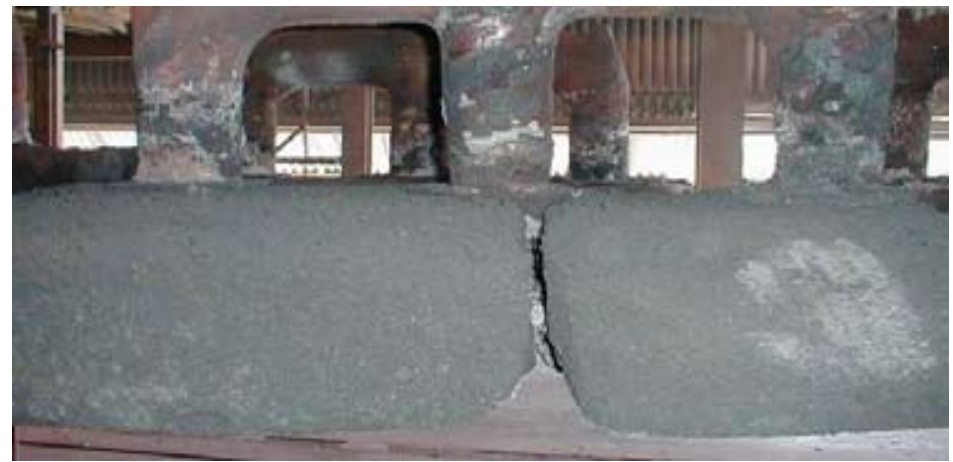

Fig. 8. Vertical thermal shock crack that has propagated up through the anode, and then been opened up by Carboxy attack in the cell

and the anode is weak enough, initiate a new crack that then propagates up through the anode and can be present in the butt (Fig. 8), or be consumed during the life of the anode.

- Late rota anode cracking occurs when stresses in the anode generated by the thermal expansion of the stubs and/or yoke assembly cause the anode to crack vertically late in the anode cycle (Fig. 4). These cracks remain in the anode/butt and can result in carbon pieces detaching into the cell, or falling off during butt processing in the Rodding Room. Late rota cracking is still damaging to cell performance, even if pieces don't detach from the anode. It results in increased cell Voltage by relieving pressure at the Stub-Carbon connection, and often allows bath attack of the Cast Iron thimble which increases iron in aluminium metal. Anode pieces can also detach during anode replacement if, e.g. the anode butt corner is hit during crust breaking with a jack-hammer prior to anode changing.

Irrespective of whether anode carbon pieces become detached due to thermal shock or late rota cracking, every effort must be made to remove them from the cells, or problems such as spikes and dusting will get out of control.

Anode problems can increase cell electrical losses (i.e. increasing $\mathrm{mV}$ losses) above the minimum necessary

These $\mathrm{mV}$ losses can be caused by:

- Poor Stub - Carbon Connections (Penalties of up to 50-80mV) (Fig. 9), 


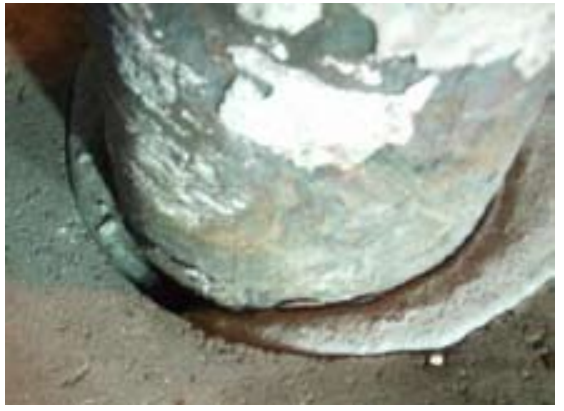

Fig. 9. Poor Stub-Carbon Connection with a "cold shut" defect in the Cast Iron thimble

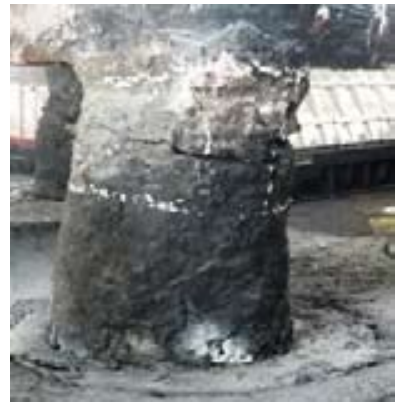

Fig. 10. Cracked stub

- Other poor anode electrical connectors or connections (stub/yoke/rod welds, transition joint ("clad") connections, anode rod to clamp connection) (Fig. 10),

- High resistance anode carbon structure caused by underbaking,

- High resistance anode carbon structure caused by internal cracking, or

- Short circuiting of the anode to the metal cathode pad by spikes (or "mushrooms").

Uneven current distribution through the anodes in a cell can also upset cell operations. This can be caused by cell related factors, as well as anode issues such as:

- Internal anode cracking,

- Variation in anode properties,

- Variable quality Stub-Carbon Connections, including partial or full connection failure,

- Variation in the condition of rod assemblies, or

- Anode failure by thermal shock or late rota cracking.

\section{Excess anode consumption}

Meaning consumption is greater than the theoretical minimum of $0.334 \mathrm{kgC} / \mathrm{kgAl}$ from the reaction $2 \mathrm{Al}_{2} \mathrm{O}_{3}+3 \mathrm{C} \rightarrow 4 \mathrm{Al}+3 \mathrm{CO}_{2}$ at $100 \%$ current efficiency. Excess consumption mechanisms include the loss of anode carbon due to the reaction with oxygen in air to form $\mathrm{CO}$ or $\mathrm{CO}_{2}$ ("Airburn"), reaction with carbon dioxide generated in the cell to form CO ("Carboxy" attack), or electrolytic attack of the anode in low current density areas such as the anode side to produce $\mathrm{CO}$ (according to $\mathrm{Al}_{2} \mathrm{O}_{3}+3 \mathrm{C} \rightarrow 2 \mathrm{Al}+3 \mathrm{CO}$ ). All of these upset cell operations to varying degrees:

- Airburn (Fig. 11) consumes anode carbon without producing metal, is an exothermic reaction that can upset cell heat balance, generates dust, and can result in the anode detaching from the rod (i.e. becoming a "burn-off") if severe enough.

- Carboxy attack (Fig. 12) occurs within the anode pore structure above the working face and in from the anode side. It is a selective reaction (preferentially attacking the binder carbon in the anode structure) that generates dust and does not produce metal hence represents the waste of anode carbon.

- Low Current Density electrolytic attack of the anode vertical surfaces (i.e. submerged anode sides \& slot surfaces) is selective and causes dust (Fig. 13). It also increases anode consumption directly as the product is $\mathrm{CO}$ and not $\mathrm{CO}_{2}$.

Disruption to the cell heat balance can occur by several anode related mechanisms 


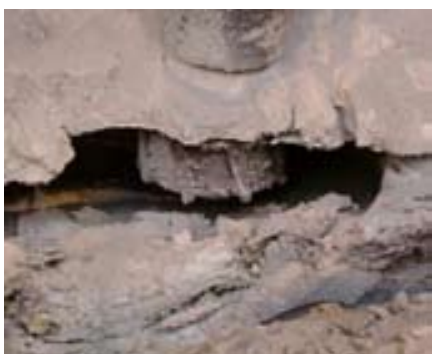

Fig. 11. Anode airburn

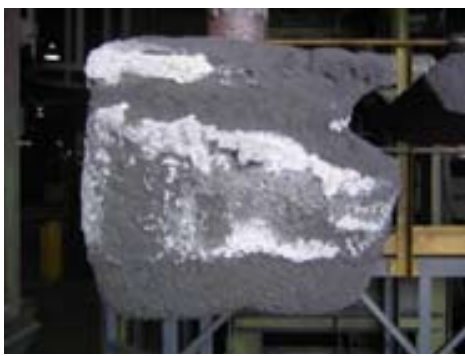

Fig. 12. Carboxy attack below the anode bath line

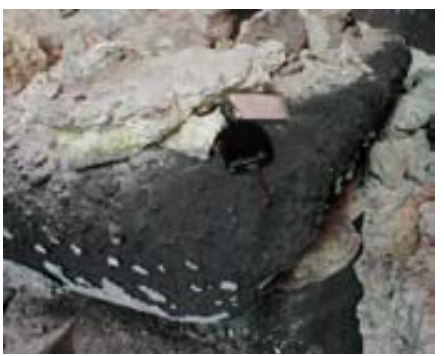

Fig. 13. Soft butt side surfaces from low Current Density electrolytic attack and carboxy attack

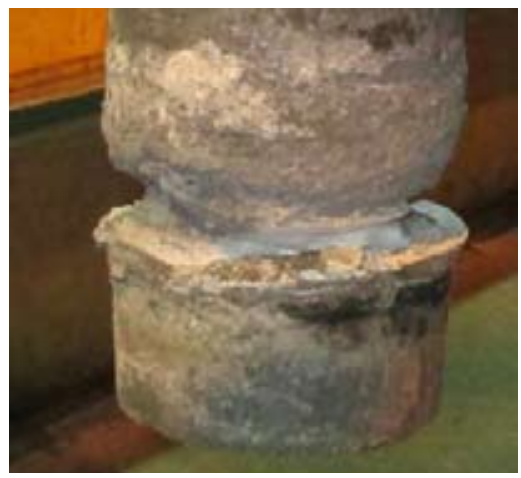

Fig. 14. Stub flux wash, or "ring-necking"

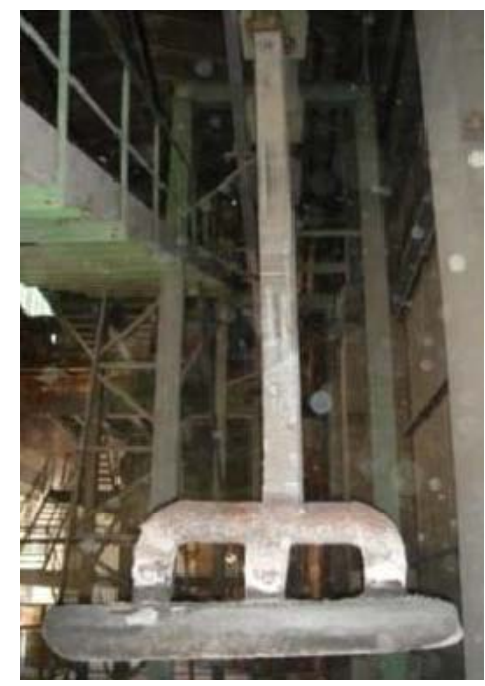

Fig. 15. Bent rod - this affects the Anode Cathode Distance in the cell and is not acceptable with new anodes

- Restricting heat flow up the stub/yoke/rod assembly due to damage or erosion of the rod component cross-section, e.g. "ring necking" of stubs (Fig. 14), erosion of the bottom of yoke arms, or damage to the transition joint.

- Excessive heat generated on the anode upper surfaces by Airburn.

- Heat generated in the Anode Cathode Distance by the presence of dust, or the back reaction of aluminium and $\mathrm{CO}_{2}$ to form $\mathrm{Al}_{2} \mathrm{O}_{3}$.

- Excessive heat generated in the anode by high resistivity carbon or by anode cracking.

\section{Poor anode geometry}

Any distortion of the anode and rod assembly can cause problems in the cell by affecting the Anode Cathode Distance, and hence cell performance. This distortion can include:

- Bent rod (Fig. 15), yoke arms, or stubs.

- Poor Stub - Carbon connection geometry, i.e. the anodes have been cast with the stubs incorrectly aligned in the stubholes (Fig. 9). 
- Distortion of the anode, e.g. bulging of the top or bottom.

These defects should not be tolerated as they impact cell performance and are the result of poor Rodding Room, or Baking Furnace standards.

Anode failure in the cell

If part or all of an anode detaches from the rod while in a cell, the results can be disastrous for cell performance. These failures can be due to factors such as:

- Excessive airburn around stubholes (Fig. 11);

- Thermal shock cracking (Fig. 5-7);

- Late rota cracking (Fig. 8);

- Failure of the Stub - Carbon connection;

- Failure of stub weld repairs (Fig. 10);

- Failure of rod transition joints;

- Excessive flux wash of the stubs (Fig. 14);

Contamination of the metal and bath in the cell from the anode can be due to anode impurities such as:

- Iron, silicon, nickel, and vanadium that contaminate the aluminium metal.

- Phosphorous, which is a bath contaminant that can accumulate and affect cell Current Efficiency.

In addition to the anode related issues that impact cell performance, the way the cells are operated also impacts anode and cell performance. These include:

- Anodes not set to the correct height, especially if set low.

- Anodes allowed to slip in the clamps until they become cathodic.

- New anodes being set on "muck" or broken anode pieces resulting in spikes.

- Anodes are poorly covered with bath/ore, initially and in redressing, that doesn't protect the anodes from airburn.

- Anodes are over-insulated on top from excessive anode cover. This overheats the anode top and can accelerate airburn and damage the rod assembly (e.g. it accelerates "toe-in" bending of stubs, and causes thermal damage to the transition joints) (Fig. 16).

- Liquid bath levels are high and variable, resulting in flux wash of stubs and dissolution of the protective anode bath cover. This increases iron in the metal and can expose the anode to airburn.

As these are the result of actions/inaction by potlines, they are not addressed further in this paper.

Critical issues in anode production to achieve good anode

and cell performance

The previous section outlines a number of ways that anode performance can affect the overall electrolytic cell process for producing aluminium. This section will now look at some of the anode quality issues that can lead to these potline problems. Some of the key control points in the production of quality anodes will be addressed; however, as the list of these control points is extensive, the focus will be on a "vital few" factors within each area of anode production that are considered most important 


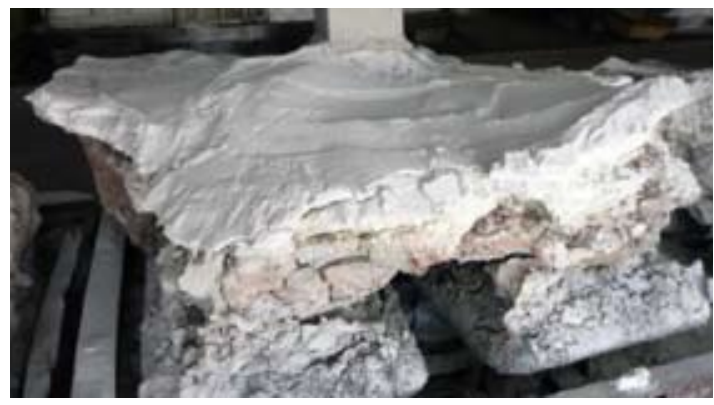

Fig. 16. Over-covering of an anode - this can damage the anode rods, accelerate toe-in, and cause thermal damage to the transition joints. Anode cover should be uniform and high enough to give protection from airburn, but low enough to allow air to circulate around and keep the yoke arms cool

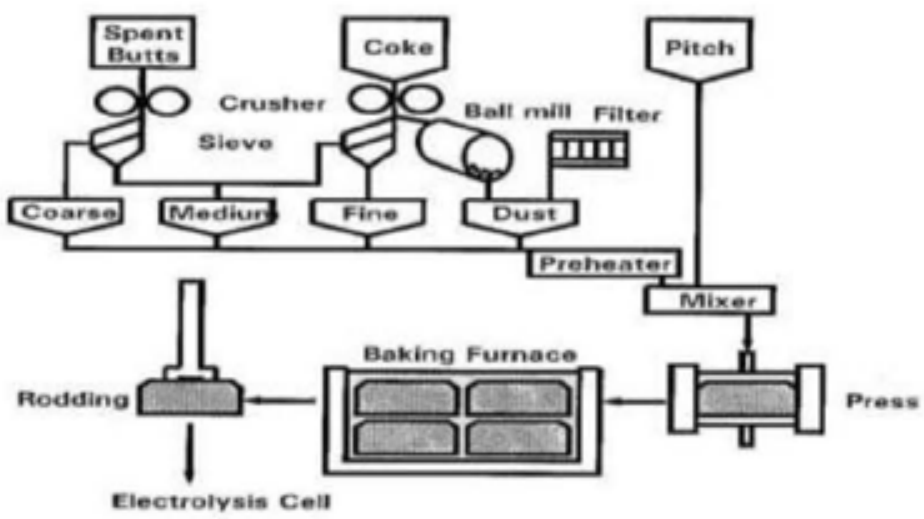

Fig. 17. Simplified anode production flowsheet (From R\&D Carbon)

and that must be addressed. In addition to these control points, the nature of Anode-Cell interactions that can lead to major process upsets will also be outlined.

As a reference point, a simplified anode production flowsheet is shown below (Fig. 17). This section of this paper will generally follow the flow of process steps in this figure, after addressing the issue of how data is used.

\section{Anode manufacturing process - using data}

The high level process map for producing quality anodes to meet the needs of the Customer is shown in Fig. 18. It is important to note that in this paper, quality means anode properties and performance that meet the Customer's requirements - they are "on target with minimum variation". This is not the same as just meeting a product specification (which is usually arbitrary), i.e. just reporting that an averaged parameter is in specification, or "in the channel" is not sufficient for good process management. There is a need to identify the "signals" in plant, process, and anode quality data that indicate that actions are required (or not) to maintain the process on target with minimum variation, i.e. to take action before specification limits are reached - this is the "action before damage" approach.

As a general statement, anode and paste producers are not good at extracting full value (e.g. not identifying all the signals in the data that action is required) from the data collected - of which there 
is normally a vast amount, but most of which is just used for filling out reports. The most important reason to collect data is to analyse it and then take action accordingly to improve the process - just using data to populate reports and explain what went wrong or right does not make better anodes. Once a signal for action has been identified from the analysis of the information collected, it is essential that an appropriate action or response is then made to address the issue.

\section{Key raw material properties}

There are several anode raw material properties that are considered to be of particular importance as they have a strong influence on the anode production process. Data collection, analysis, and responding to these properties should be done in the same way as for process data, as shown in Fig. 19.

\section{Pitch}

Looking at pitch properties from the perspective of their impact on processing conditions, the most important Coal Tar Pitch (CTP) properties are considered to be those listed below. Note that just because other properties are not listed does not mean they are not important; it is just that the following are considered more important from an anode production perspective.

- QI, or Quinoline Insolubles (analysed, not calculated), including primary QI (inherent in the coal tar), or secondary QI (mesophase) formed during pitch heat treatment. QI in pitch affects the "pitch demand" of the paste (See Table 1 later for details), and pitch level adjustments must be made if QI levels change significantly. Mechanically weak anodes can result at very low QI levels, e.g. $<\sim 2 \%$.

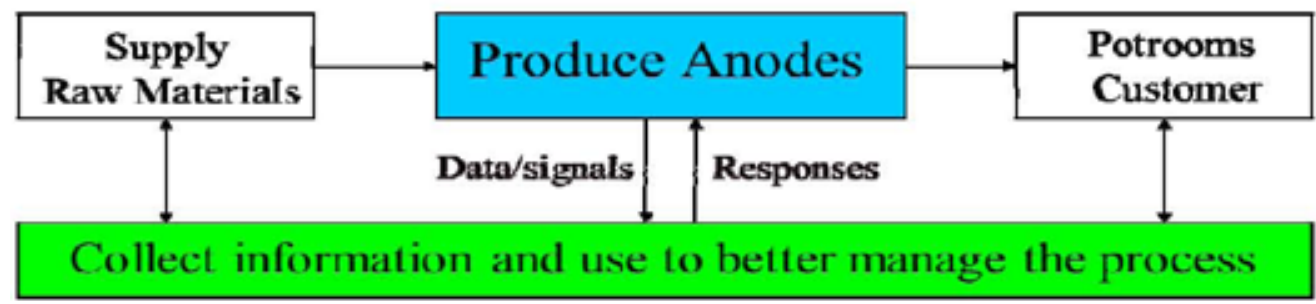

Fig. 18. High level process map for producing quality anodes to meet the needs of the Customer, highlighting the important role of data collection, analysis, and response to signals identified in the data

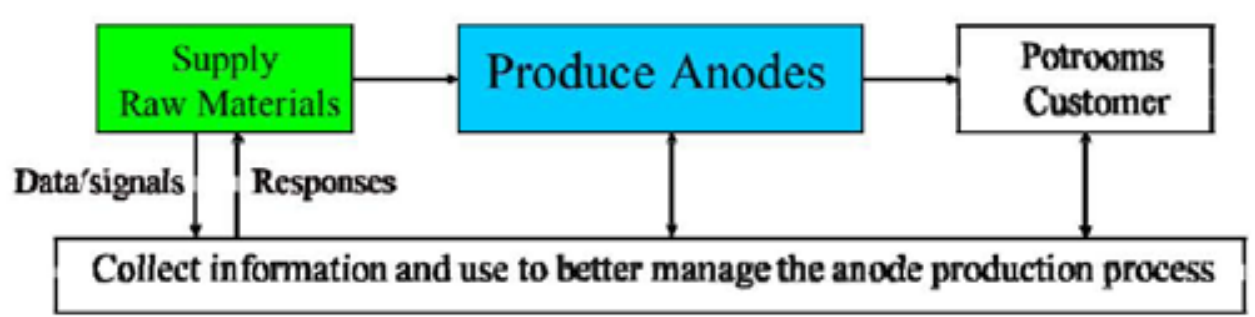

Fig. 19. In addition to ensuring compliance to purchasing agreements, i.e. checking that you are getting what you pay for, data is collected on raw material properties in order to adapt processing to maximise anode quality from available raw materials. At this early stage in the process, it is essential to respond to any signals in the raw material data, taking action before damage 


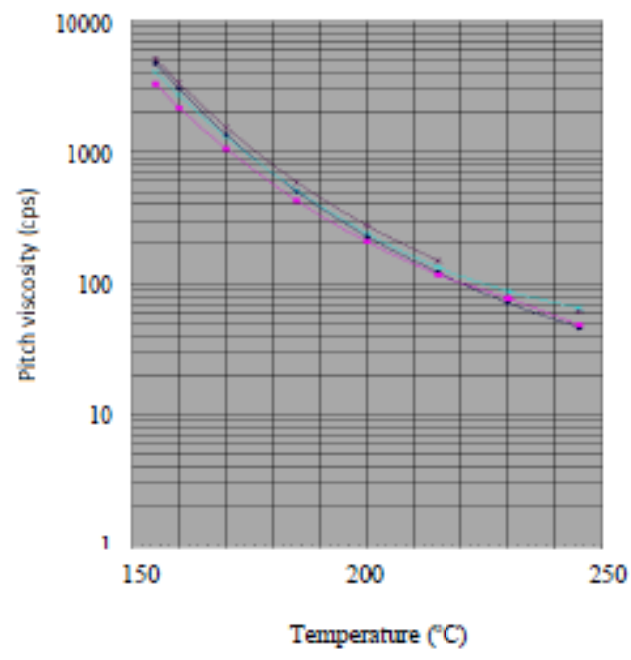

Fig. 20. Pitch viscosity-temperature curves. These are important for setting paste processing temperatures in order to maintain high anode density and overall quality

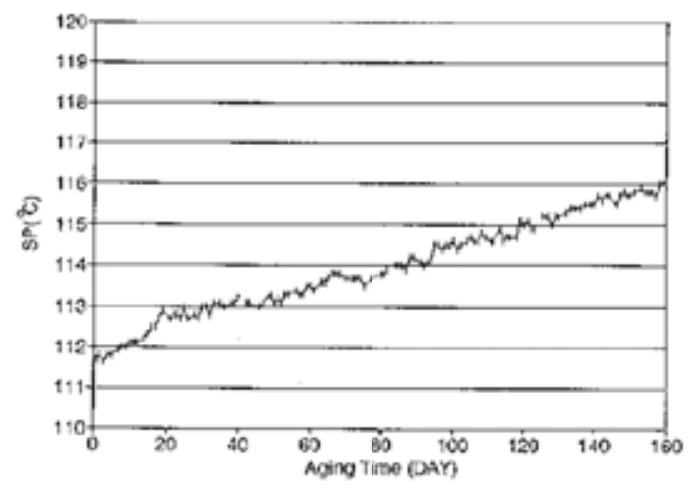

Fig. 21. Pitch ageing in storage. Processing temperatures may need to be adjusted to compensate for these changes [3]

- Real Density. Pitch levels are optimised in green anodes on the basis of volume (i.e. what volume of pitch is needed to coat the coke particles and then fill the inter and intra particle porosity); however, pitch additions to paste are metered and monitored in the plant as a mass flow (rate), so any change in pitch density may require adjustments in pitch addition rate to compensate and maintain the optimum pitch level. Pitch Real Density is also an indicator of the average molecular weight of the pitch, and hence is a predictor of important properties such as coking value.

- Viscosity-temperature profile. The viscosity of pitch at mixing, cooling, and forming temperatures is a key determinant of the optimum paste processing temperatures. The viscositytemperature relationship should be known for each pitch used, with processing temperatures modified as necessary based on pitch viscosity (Fig. 20).

- Thermal stability is an important pitch property for prebake anode production where process temperatures may need to be increased as liquid pitch "ages" as it is held in storage (Fig. 21), but is even more important to give the desired soft zone properties in Söderberg anodes.

\section{Coke}

In the same way as pitch, the most important filler coke properties are determined by their influence on the anode processing conditions and are considered to be those listed below. Note that just because other properties are not listed does not mean they are not important; it is just that the following are considered more important from an anode production perspective.

- Vibrated Bulk Density (VBD). This is a measure of the porosity of the coke in a mono-sized packed bed. While an imperfect test (as it does not translate well to the packing of aggregate particles), VBD is useful as a predictor of anode density, and helps to estimate changes in the optimum pitch level (Table 1). 
Table 1. Some of the key factors that influence paste pitch demand, and hence the optimum pitch level of Green Anodes (Source: Hulse thesis published by R+D Carbon)

\begin{tabular}{|l|c|}
\hline \multicolumn{1}{|c|}{ A change of: } & Impact Pitch Demand by: \\
\hline +/- Coke VBD by 0.01 g/cm3 & $-/+0.125 \%$ \\
\hline +/- Fines content by 10\% (@ 3000 BI) & $+/-1 \%$ \\
\hline +/- Fines fineness by 1000 BI (@ 30\% Fines) & $+/-1 \%$ \\
\hline +/- Mixing Temperature $1{ }^{\circ} \mathrm{C}$ & $-/+0.15 \%$ \\
\hline +/- Pitch (Mettler) Softening Point $10^{\circ} \mathrm{C}$ & $+/-0.6 \%$ \\
\hline +/- Pitch Primary QI $1 \%$ & $+/-0.14 \%$ \\
\hline +/- Pitch Mesophase $1 \%$ & $+/-0.17 \%$ \\
\hline +/- Butts 10\% & $-/+0.6 \%$ \\
\hline
\end{tabular}

- Real Density (RD). As discussed in section B.7, it is desirable to match binder and filler coke structures during baking, so changes in coke RD may need to be matched by changes in baking temperature.

- Sulphur content. As discussed in section B.7, increasing sulphur in coke can make the coke more sensitive to thermal desulphurisation with overbaking, so changes in coke sulphur level may need to be matched by changes in baking temperature.

\section{Green Anode production - key parameters}

The key factors associated with making good Green Anodes include:

- Consistent material transport and handling (minimal particle size segregation, and even flow from storage facilities).

- Consistent aggregate particle size, especially the finest and coarsest material (on target with minimum variation).

- Optimal and controlled pitch additions (on target with minimum variation).

- Effective mixing so that all aggregate surfaces are coated with pitch and inter and intra particle porosity is filled with pitch or a pitch/fines mixture.

- Effective compaction, so that anodes are formed to a maximum density without introducing cracks or other flaws into the anode structure.

In the following, selected topics related to the key Green Anode production parameters are covered in more detail:

1. Making Green Anodes (GA) is largely about transporting materials around the plant, with heat and pressure added in a few of the production steps. Given this, consistent material handling with minimal segregation and even, stable flows from storage vessels such as silos are key requirements of making consistent quality anodes. Segregation can be the largest source of variation in GA properties. Every movement of coke results in segregation, with the rolling of coarser particles to the outside of silos and stockpiles - "sifting" segregation (Fig. 22, 23), one of the common examples.

Feeding coke in and out of silos can cause flow problems, especially in older designed facilities where minimising segregation was not a prime design criteria. Coke or butts particles will segregate 


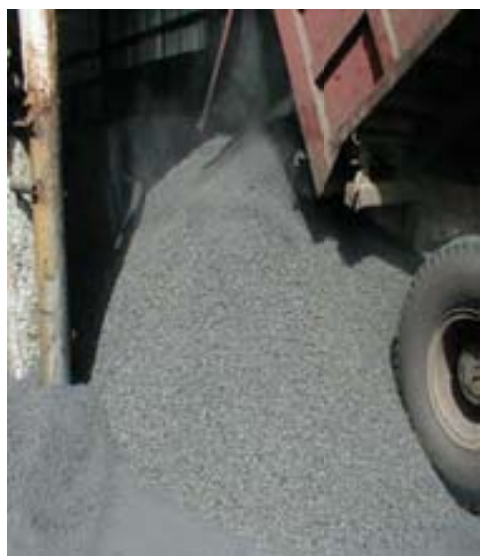

Fig. 22. Segregation during handling - larger particles roll down to the outside of the stockpile. The same effect occurs in silos as they are being filled

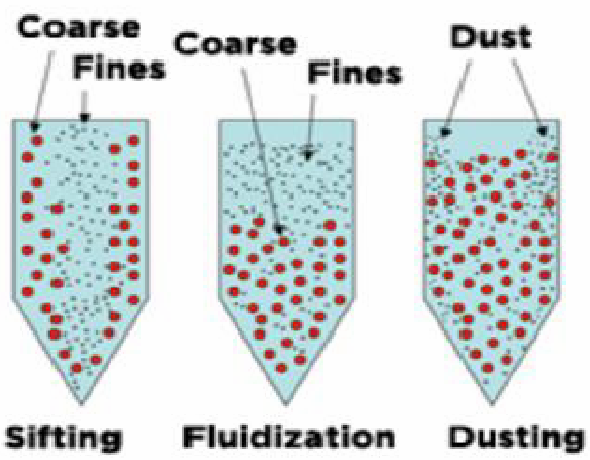

Diagram source: Jerine Jaharach com

Fig. 23. Segregation associated with the filling of silos. Sifting segregation is common in Carbon Plants

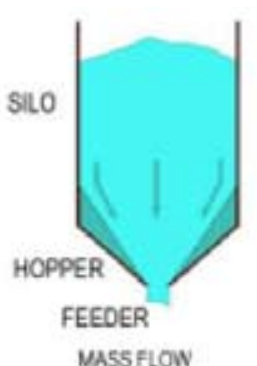

MA5SFLOW

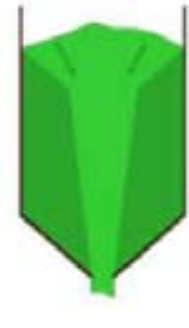

FUNNEL FLOW

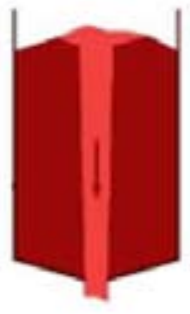

RATHOUNG

Fig. 24. Modes of flow from silos. Mass flow is desired as this minimises segregation (Diagram source: unknown)

during silo filling (Fig. 23), and various flow problems can be encountered as the material is discharged from the silo (Fig. 24):

- Funnel flow

- Rat holing

- Erratic flow

- Flooding or flushing

The result of these segregation and flow problems is variation in the particle size and other properties of material streams within the Green Anode production process, and these will end up as variation in overall Green Anode quality and properties such as density.

These segregation and flow problems are now well understood and can be addressed by improvements to the materials handling systems used and/or modifications to operating procedures so that silo levels are maintained in the range $40-60 \%$ full wherever possible, and cycling silo levels between empty and full is always avoided.

2. The fine and coarse ends of the anode aggregate particle size distribution are the most important in determining key anode properties, hence maintaining a good target and high consistency of these is important. 
The fine coke in the aggregate provides about $80 \%$ of the surface area that has to be coated with pitch; hence stability of the fines and dust fractions in the aggregate is essential to maintain the optimal pitch level and key anode properties. To do this, the Ball Mill Product (BMP) must be on target with minimum variation. Typical sources of variation in BMP that must be controlled include:

- Variation in ball mill feed size.

- Variation in mill feed rate.

- Uncontrolled adjustment or wear of the classifier.

- Wear of grinding balls (with an inadequate replacement cycle), and mill grates.

- Variation in mill circuit airflows and pressure differentials.

- Poor management of dust additions to the mill circuit or fines product.

Each of these, and numerous other factors, must be controlled to achieve a consistent fine coke in the aggregate.

Blaine Index (BI) is an excellent control measure of the fineness of the Ball Mill Product or dust in the aggregate, as it is a single point measure that incorporates the very fine, high surface material that is not measured by normal screen analysis. This superfine material must still be coated by pitch to ensure good anode quality, hence it is important to maintain stability of the fines and dust BI. The variation in Fines fraction BI evident in Fig. 25 will cause variation in paste and anode properties.

In Fig. 25, it can be seen that the Fines Fraction Blaine Index shows excessive variation, whereas the Ball Mill Product is reasonably stable, i.e. variation is within the normal standard of $(+/-10 \%$ of the value). In this case the problem was the uncontrolled addition of very fine material (very high BI) from plant dust collectors to the Ball Mill Product; the good control of the Ball Mill was lost and anodes were being made with unacceptably variable Fines material. Good pitch level control was virtually impossible in this case and anode quality was unnecessarily variable.

3. Coarse particles in the aggregate. In order to make a quality baked anode with high density and acceptable other properties such as Air Permeability, the anode aggregate must pack together

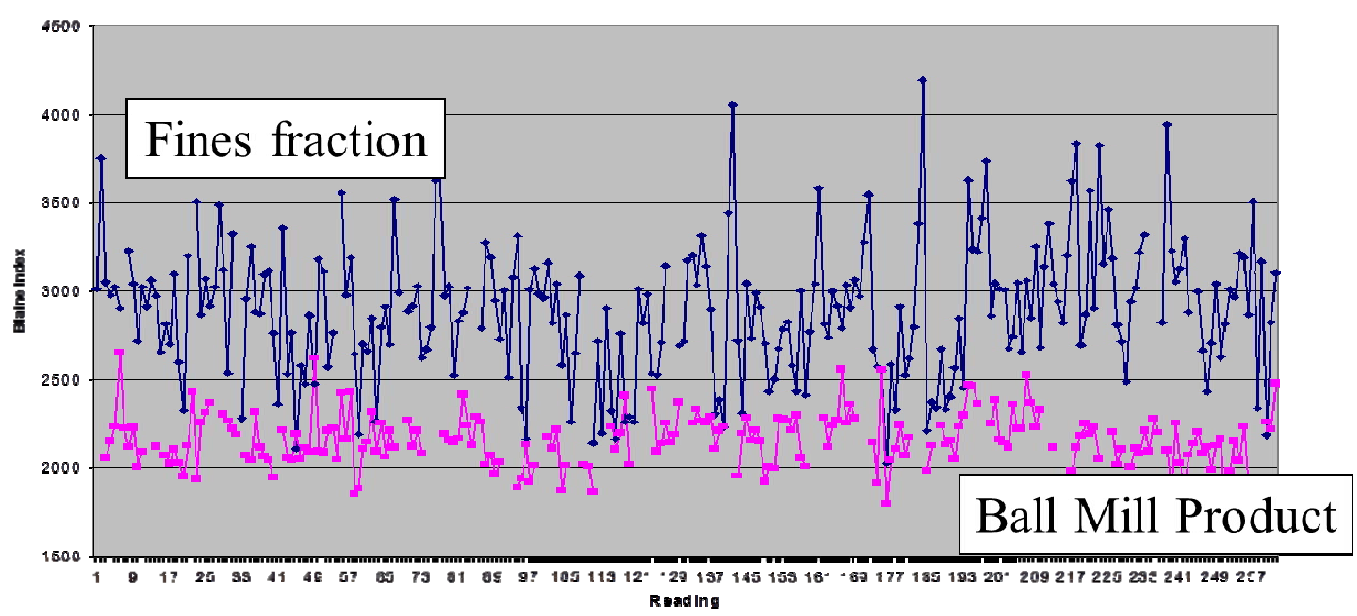

Fig. 25. Blaine Index results for Ball Mill Product (BMP) and the Fines Fraction (= BMP + Plant Dust). The variation in $\mathrm{BI}$ for the BMP is generally within normal limits ( $+/-10 \%$ of the value); however the Fines Fraction $\mathrm{BI}$ is highly variable 


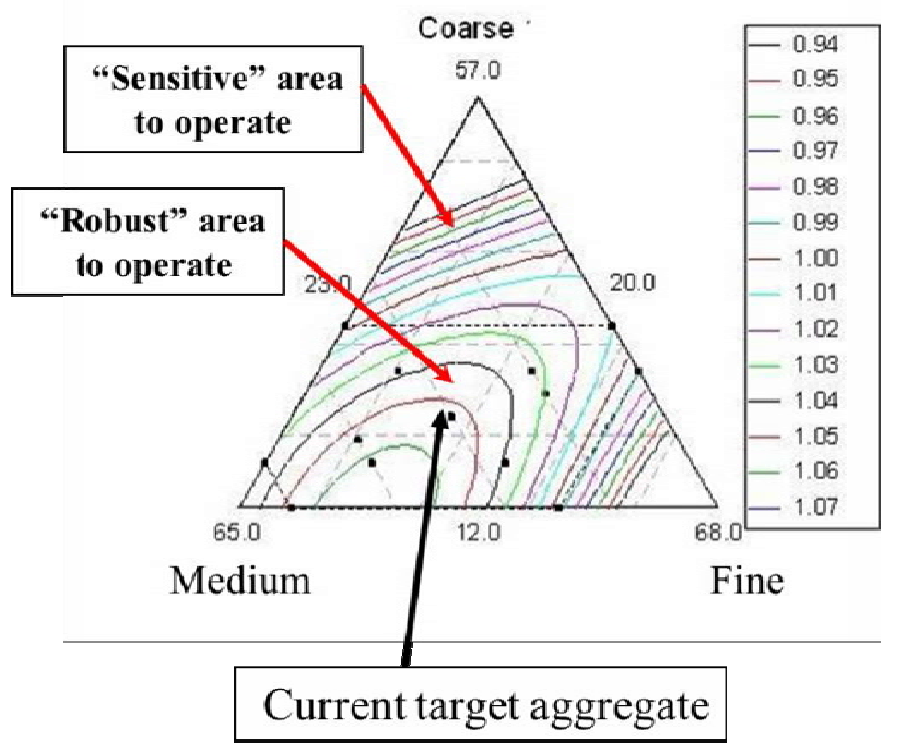

Fig. 26. Aggregate VBD as a function of Coarse, Medium, and Fine coke fractions in the aggregate

reasonably well, i.e. the aggregate Bulk Density must be acceptable to give good anode properties. If the individual butts and coke fractions are stable, there will be a combination of these that gives the maximum Vibrated Bulk Density of the total aggregate. To set the target plant fraction recipe, this combination (which can be determined experimentally and plotted as shown in Fig. 26), will then need to be modified to achieve other necessary properties such as paste formability, robustness, and to meet the needs of the plant mass balance.

It can be seen that in the high Coarse area of Fig. 25, aggregate VBD is sensitive to variation in the amount of the coarsest material in the aggregate (i.e. butts in prebake anodes). Variation in this coarse material disrupts packing and strongly impacts anode quality, causing large variability in key anode properties such as Baked Apparent Density and Air Permeability.

In order to produce high quality anodes, the aggregate particle size must be stable, especially at the fine (i.e. a consistent Blaine Index for good pitch level control) and coarse (for good aggregate packing) ends of the distribution. This requires that material transport (e.g. no segregation), screening, crushing, grinding, and proportioning processes are well monitored, and maintained on target with minimum variation.

4. Mixing: the purpose of mixing anode paste is to coat the aggregate surface with pitch, penetrate pitch (and fine coke) into the accessible coke porosity, to fill the voids between aggregate particles with pitch and coke fines, and to prepare a homogeneous paste for the forming process. Mixing can be done in batch, or more commonly in modern plants, in continuous mixers.

To achieve a satisfactory mixing effectiveness, the paste temperature must be on target (set to achieve a target pitch viscosity as defined by the pitch viscosity-temperature relationship, Fig. 20) with minimum variation, and the flow rate of fractions and pitch through the mixer must be consistent, which infers accurate and consistent fraction and pitch proportioning. The net energy imparted to the pitch during mixing should be $\sim>8 \mathrm{kWh} /$ tonne. 

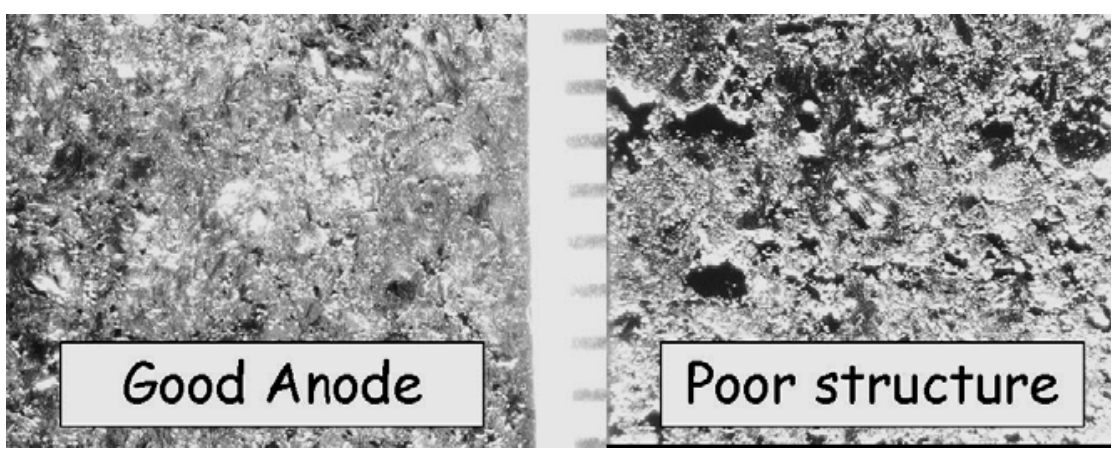

Fig. 27. Baked anode structures resulting from good (left) and poor (right) mixing and compaction

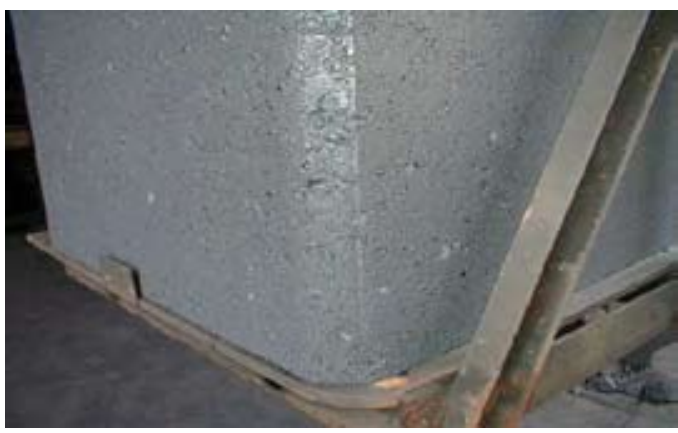

Fig. 28. Left, Butt particles on the Green Anode surface that have not been wet by pitch during mixing, which is a signal of poor mixing effectiveness

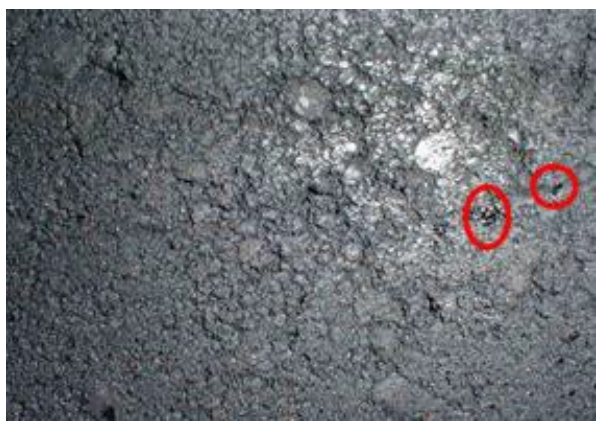

Fig. 29. Right, "blobs" of unmixed pitch on the Green Anode surface which is another signal of poor mixing

Signals that mixing is not adequate for good paste quality include the poor dispersion of pitch within the paste, non-wetting of particles in the paste, and regions of poor anode structure ("compaction faults") giving localised high permeability and reactivity, which in turn can lead to areas of dusting from the anode in the cell. Examples of well and poorly mixed baked anode macrostructures are shown in Fig. 27. Excessive wear of the mixer shaft or stationary teeth in continuous mixers is a common cause of ineffective mixing. These components should be inspected regularly, resurfaced with hard facing weld metal as required, and refurbished routinely about every 100,000 tonnes of paste produced.

The surface appearance of Green Anodes also gives signals of poor mixing quality, with butt particles that have not been coated with pitch evident on the surface of the green anode before cooling (Fig. 28). Small "blobs" of unmixed pitch may also be seen with poor quality mixing (Fig. 29).

5. Pitch addition: each unique combination of aggregate particle size (especially the Blaine Index of the fine material), pitch properties, coke properties, and plant operating parameters, will result in a pitch level that will give the optimal baked anode properties (Fig. 30).

There are numerous factors that influence optimum pitch level; some examples are shown below: 


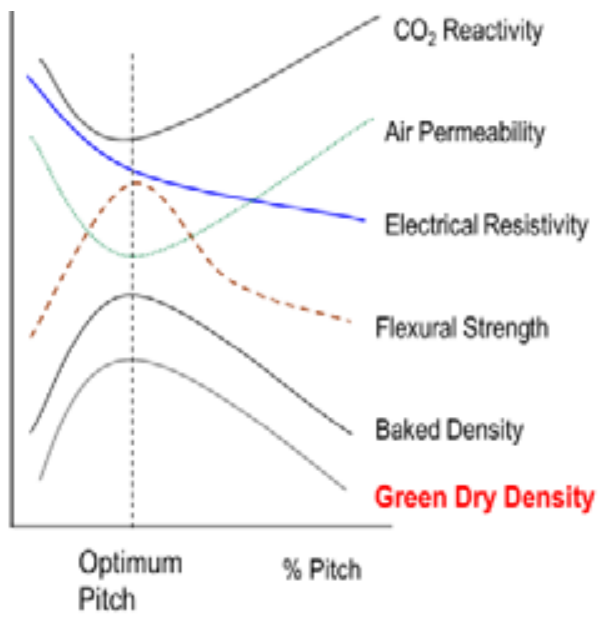

Fig. 30. Effect of pitch level on anode properties, showing the tendency to optimise at a single pitch level. Operating at this pitch level is an objective of Green Anode manufacture. Green Dry Density is a parameter calculated from the measured Green Anode Density [GDD = Green Anode Density $(100-\%$ Pitch $) / 100]$ that can be used to predict the optimum pitch level from Green Anode properties

Each of the factors shown in Table 1 must be maintained in a stable state; if that is not possible, changes must be responded to in an appropriate way to maintain the optimum pitch level, and hence optimal anode properties.

6. Anode (vibro)forming. The objective of anode (vibro)forming is to shape paste into consistent quality Green Anodes at the highest green density without over-compacting the anode. High green density can be achieved by optimising the paste properties, and then forming this paste under optimal conditions (temperature, forming time, vibration frequency/amplitude, forming force, etc). It is important that Green Anodes have a high degree of structural integrity, i.e. that there are no internal cracks, flaws or other faults.

Modern vibroformers can apply force to the paste via airbags pushing on the coverweight. This enables the relative motion of the mould box and coverweight to be synchronised, thereby giving a desirable increase in compaction efficiency. The airbags can also be used to simply increase the intensity of compaction with the aim of increasing anode green density; however just increasing forming intensity to improve anode density is risky as it can result in overcompaction and anode cracking.

Overcompaction results in internal cracking in anodes as shown in Fig. 31. This internal cracking can be very damaging to anode performance and, in the worst case, can result in anode failure (Fig. 6, 7) that can severely impact cell operations. If the anodes remain intact, the cracking disrupts current flow in the anode and can cause localised heating and "scalloping" airburn. Applying additional force during compaction as a "band-aid" to regain lost density due to up-stream problems with raw materials or paste quality is not appropriate - it is better to address the upstream problems directly than apply the band-aid.

Poor structural integrity in formed anodes can also result from the segregation of paste within the anode as shown in Fig. 32. Segregation of butts within the anode results in variation in anode properties - areas of high butts concentration means there are areas of low butts in the anode and hence 


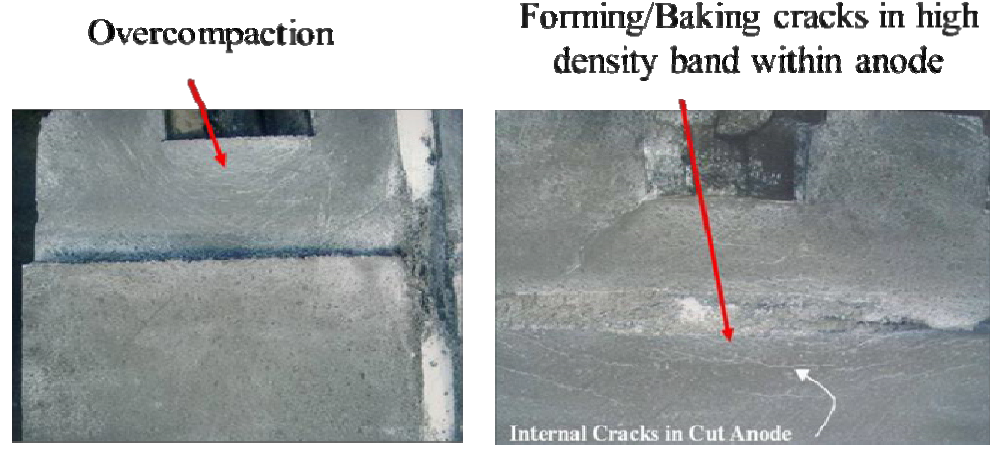

Fig. 31. Cut anode photographs showing internal cracking in baked anodes resulting from overcompaction of the Green Anode. This poor structural integrity is very damaging to anode and cell performance. These are Green Anode defects that may not be evident until after baking

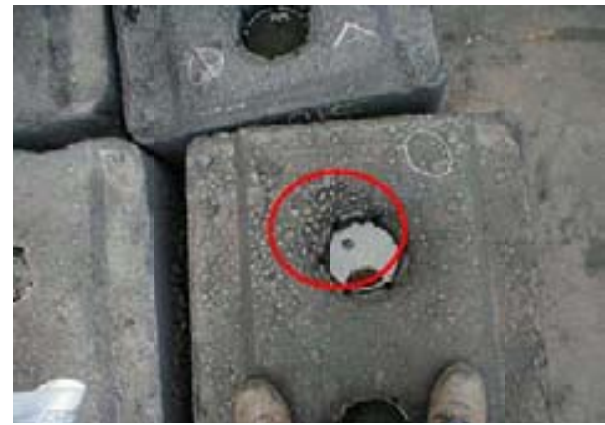

Fig. 32. Segregation of butts is evident on the anode surface; this results in undesirable variation in anode properties

less than optimal packing as discussed previously. This variation in anode properties can impact on anode performance with areas of localised dusting, and disrupt cell current flow.

7. Cooling of Green Anodes after forming must be even (to avoid cracking) and sufficient to allow the anodes to be picked up by crane grabs for stacking. In water spray tunnels, a common problem is blocked spray nozzles leading to uneven cooling.

\section{Baked Anode production - key parameters}

The objective of baking is to transform Green Anodes into electrically conductive carbon blocks of suitable mechanical strength, low reactivity, and physical stability needed to perform in the electrolysis process. Two of the key baking process parameters are the final anode baking temperature and the anode heat-up rate.

1. Anode final baking temperature. The typically quoted target average anode baking temperature is within the range $1100+/-50^{\circ} \mathrm{C}$, with values in this range generally giving good results with a reasonable trade-off in anode properties between under and over-baking (Fig. 33). A minimum baking temperature to be exceeded by all anodes of $\sim 1050^{\circ} \mathrm{C}$ can also be used to avoid any risk of underbaking (Fig. 34). Underbaking is very damaging to anode and cell performance, often leading to severe anode dusting. 


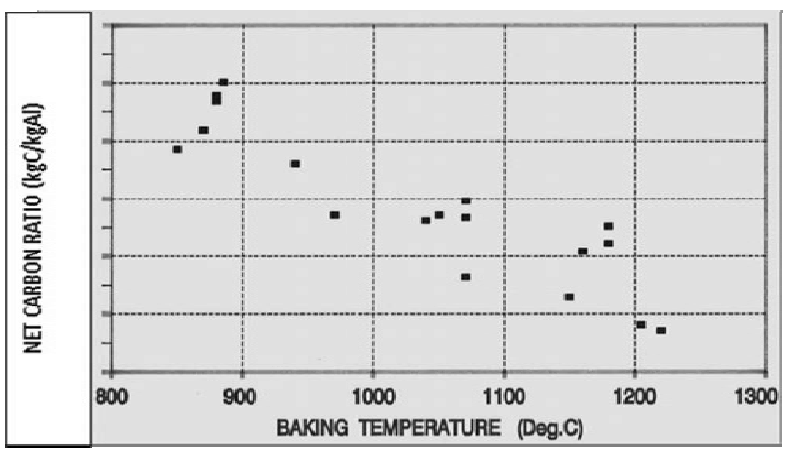

Fig. 33. Relative impact of baking temperature on measured anode consumption. The trend in these data is specific to each site, so the optimum baking temperature should be determined experimentally at each smelter

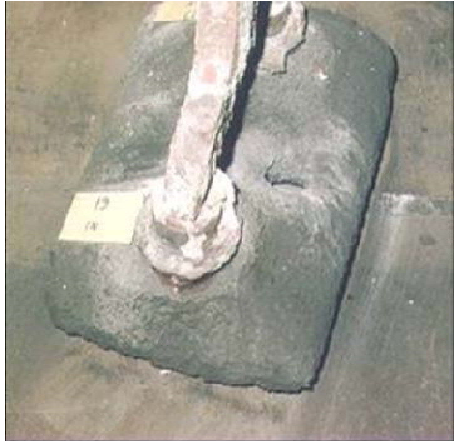

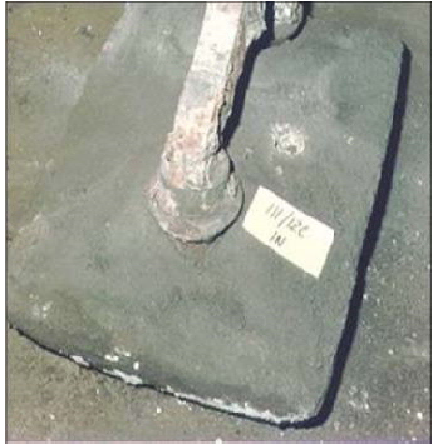

b

Fig. 34. Effect of baking temperature on anode performance/butt appearance: $a$ - underbaked; $b$ - well baked. The effect of underbaking can be clearly seen

Ideally the optimum/minimum anode baking temperatures would be determined on a smelter by smelter basis, taking into account local factors such as:

- Filler coke properties. This is an increasingly important consideration as coke sulphur levels increase, giving a greater likelihood of desulphurisation from overbaking. Desulphurisation increases anode reactivity (Fig. 35) and hence should be avoided. It is important to note that it is the properties of individual coke blend components that are important in determining the propensity of a coke to desulphurise, not the average properties of the blend.

Coke Real Density (RD) is also important, as from a structural perspective, matching binder and filler carbon properties is a desirable outcome from baking, so if coke RD increases (with higher coke calcination temperatures), baking temperatures should also be increased.

- The condition of the baking furnaces and the quality of the baking process at the smelter high quality anode baking with low variation in baking temperature can enable average baking temperatures to be reduced while avoiding underbaking.

- The reduction cells used can also impact the optimum baking temperature - older cell technologies are more sensitive to airburn due to the greater relative anode height and subsequent

$$
-563-
$$




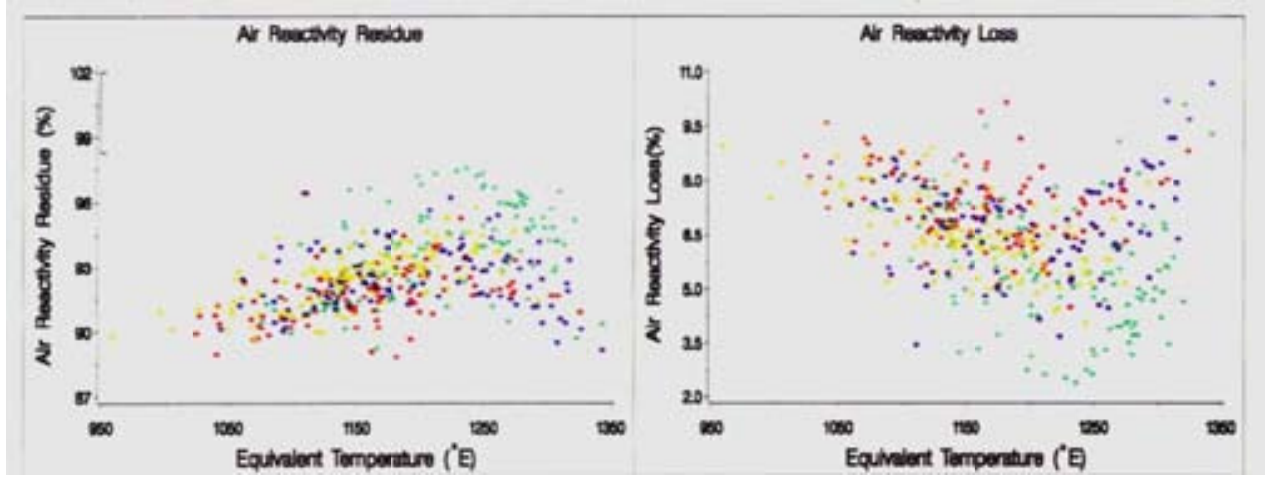

Fig. 35. Effect of overbaking/desulphurisation on increasing anode air reactivity (Equivalent temperature on the $\mathrm{x}$-axis is a measure of the temperature the anode is baked to and the holding time at this temperature. It is around $80^{\circ} \mathrm{C}$ higher than the temperature measured by a thermocouple). Data of this type can be used to determine the optimum baking conditions at any smelter (Data source: Comalco)
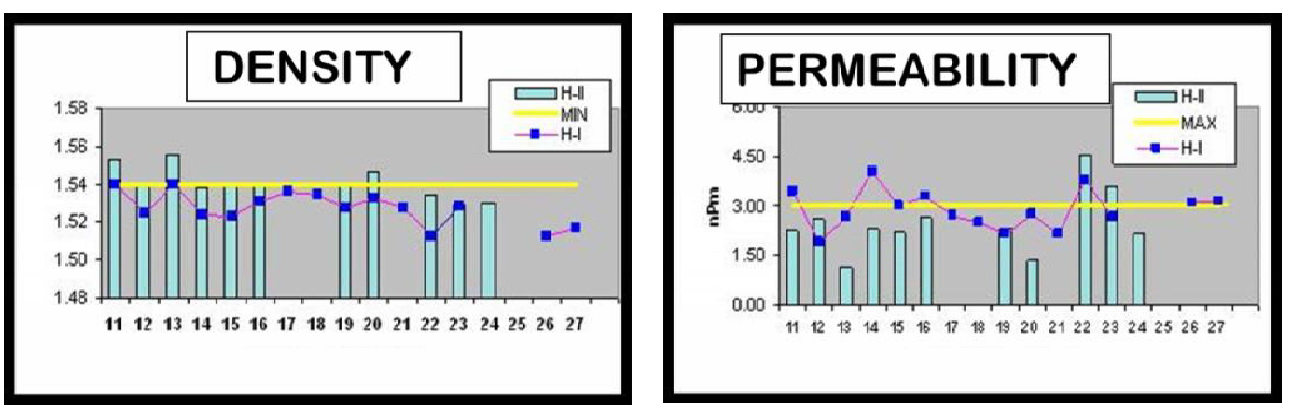

Fig. 36. Same green anodes baked in furnaces with a normal heat-up rate (Blue bars), and very fast heat up-rate (Red lines + blue dots); it can be seen that, in general, the normal heat-up rates resulted in anodes with higher Baked Density and lower Air Permeability (Data source: Alcasa)

difficulty in providing a protective covering of bath. Higher anode thermal conductivities from higher baking temperatures increase the propensity of anodes to airburn in these cells, so high baking temperatures can be an issue. More modern cell designs with point feeders for alumina and deeper cavities allow better anode protection, but are more sensitive to anode dusting (compared to older centre break and feed cells) as it is more difficult to clear dust from the modern cells. Avoiding dust by pushing baking temperatures to the high side is needed with these cells.

2. Anode heat up rate. The acceptable anode heat up rate (anode temperature in the range 200 $600^{\circ} \mathrm{C}$ ) is generally quoted as being $<12-14^{\circ} \mathrm{C} / \mathrm{h}$ to avoid the internal cracking of anodes from the pressure build-up from rapid pitch volatile release. In the extreme, very fast heat up rates can impact anode properties such as Baked Apparent Density and Air Permeability (Fig. 36). The widespread use of formed slots in anodes has reduced the sensitivity of anodes to cracking from fast heating, whereas the production of highly compacted Green Anodes using modern vibroformers has increased the likelihood of anodes cracking during baking. 


\section{Rodding baked anodes - critical issues}

The critical anode rodding issues for quality and performance include the characteristics of the Stub-Carbon Connection, and the quality of cleaning of anode butts.

1. Stub-Carbon Connection. There are numerous factors that determine the quality of the rodded anode Stub-Carbon Connection (SCC), including the composition of Cast Iron (CI) used (it should be Grey CI), and the thickness of the CI thimble, i.e. the gap between the stub and stubhole.

As the CI thimble cools after an anode is cast, the greater shrinkage of the CI relative to the anode carbon results in the formation of an "air gap" between the thimble and the anode. As a general rule, the thicker the thimble, the wider the air gap. Other factors that influence the airgap include the CI composition, the condition of the stubs (i.e. if eroded or attacked from bath), and the temperature of the stub and stubhole at casting. All of these need to be well controlled (on target with minimum variation) to achieve a consistent quality SCC.

The air gap influences the rate of current take-up by the anode after it is set in the cell, and the prevalence of late rota anode cracking due to the greater thermal expansion of the stub/thimble relative to the anode carbon as shown in Fig. 37. The optimal characteristics of the SCC that will give the best balance between early - mid rota $\mathrm{mV}$ drops and late rota cracking (and hence increased $\mathrm{mV}$ drops) needs to be established for the circumstances at each smelter.

2. Effective cleaning of butts. Whenever butts are recycled into anodes, it is essential that they are effectively cleaned of all residual bath material. This means effective precleaning and shotblasting to achieve the standard of "no white on black". If sodium and fluoride are recycled with the butt carbon, it increases anode reactivity, consumption rate, and dusting tendency. It also substantially reduces the life of baking furnace refractories. There is a very clear signal that butt cleaning needs more attention the visible appearance of the butt as shown in Fig. 38.

In addition to cleaning butts well, to control sodium in anodes it is also necessary to not recycle any anode pieces that have been "floating" in the cell, or anodes that have been "dunked" into the metal pad, as these carbons have absorbed large quantities of sodium that cannot be removed by cleaning.

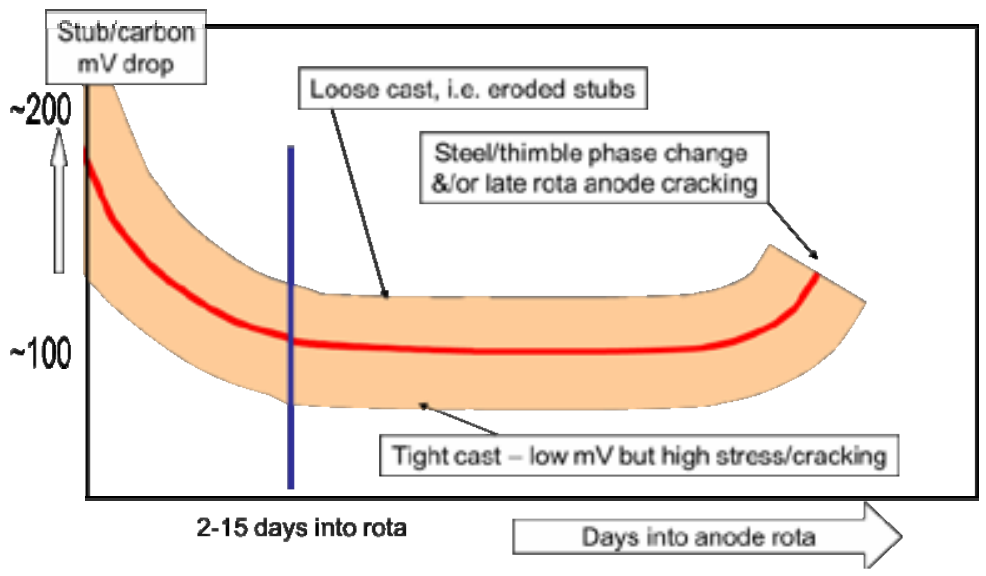

Fig. 37. Anode $\mathrm{mV}$ drops during anode rota. Large air gaps ("loose casts") result in high initial and plateau SCC $\mathrm{mV}$ drops, but little cracking of the anodes late in the cycle. Tighter casts, with narrower air gaps give lower $\mathrm{mV}$ losses early in the anode life and during the plateau, but greater cracking and higher $\mathrm{mV}$ drops toward the end of the anode life

$$
-565-
$$




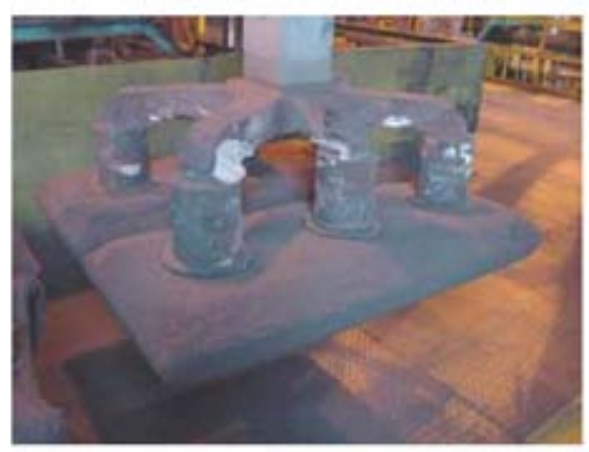

a

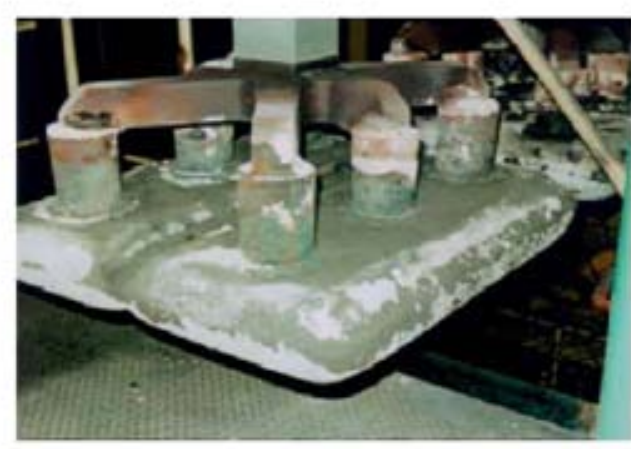

b

Fig. 38. Well cleaned (a) and poorly cleaned butt (b) after shotblasting. The remaining white on the poorly cleaned butt is a signal that the process needs attention to achieve an acceptable standard

\section{Anode-cell interaction}

When any of the preceding production and quality critical issues has not been adequately managed, there is a risk of anode performance problems, or so called "excursions". These can often be caused by short term shifts in anode properties and /or cell operations. Irrespective of the source of the shift, the cell condition deteriorates, and anodes that previously performed acceptably, now fail and cause the cells to move further out of condition. The result is a vicious cycle of anodes failing and cell condition deteriorating that can get severe enough to compromise the viability of a Potline. Escaping from such vicious cycles requires that anode quality is made more capable and robust, and that efforts are directed at recovering cell condition. This sequence is shown in Fig. 39-42.

\section{Summary}

The key objective when making anodes is to produce consistent, low variation anodes that meet your Customers' requirements with:

- Acceptable density (most other properties follow density), with

- Low variation within and between anodes, and a

- High degree of Structural Integrity - no flaws, or cracks

To do this, you must manage all of these process steps well, i.e. on target with minimum variation:

- Consistent raw material feed to plant (minimal segregation)

- Consistent fines (size and rate), and coarse material in the aggregate

- Correct and controlled pitch additions

- Effective mixing - well mixed paste

- Effective compaction - high density without cracking

- Effective baking - appropriate final temperature at acceptable heat-up rate.

- Rodding Room - adequate casting of the Stub-Carbon Connection and clean, hard butts 


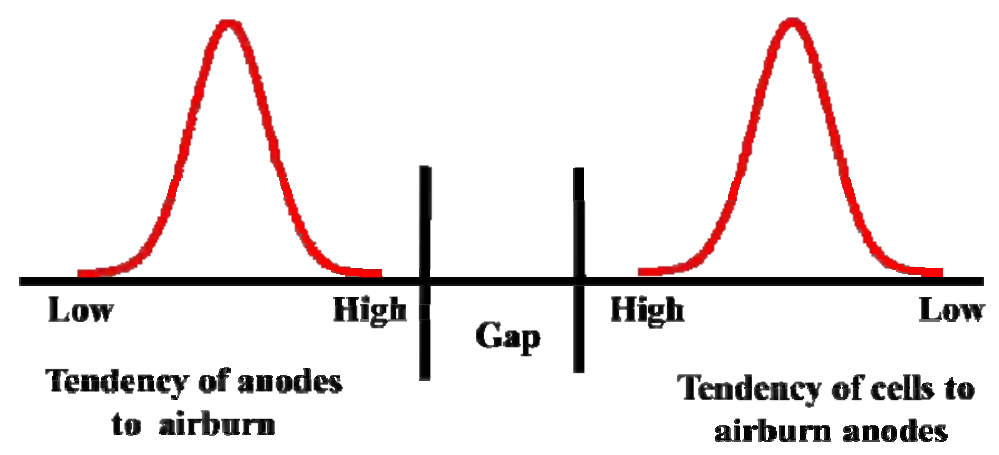

Fig. 39. Capable anode and cell performance, e.g. in the airburn example shown, the anode with the greatest tendency to airburn will still not cause a problem in the cells with the worst tendency to airburn anodes, i.e. there is no overlap in the distributions, and no airburn problems would be expected

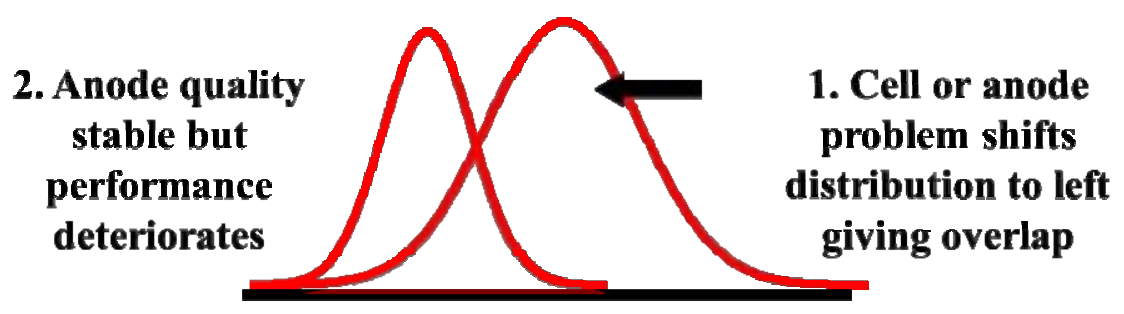

Potential anode problems

Fig. 40. Anode problem development: (1) after a problem that may have been caused by a batch of poor quality anodes (e.g. cracked) or a cell related factor (e.g. a power outage, etc), the cell condition is affected, and the propensity of cells to airburn anodes increases. (2) Even though the anode quality has returned to normal, there is now an overlap and airburn problems can be expected in some cells

\section{Anode quality stable but
performance
deteriorates
further}

More potential anode problems
3. Anode problems exacerbate cell problems and shift the distribution to give a greater overlap

Fig. 41. Development of the vicious cycle - (3) anode quality is stable, but anode performance deteriorates (4), which in turns impacts cell condition further, increasing the magnitude of anode problems 


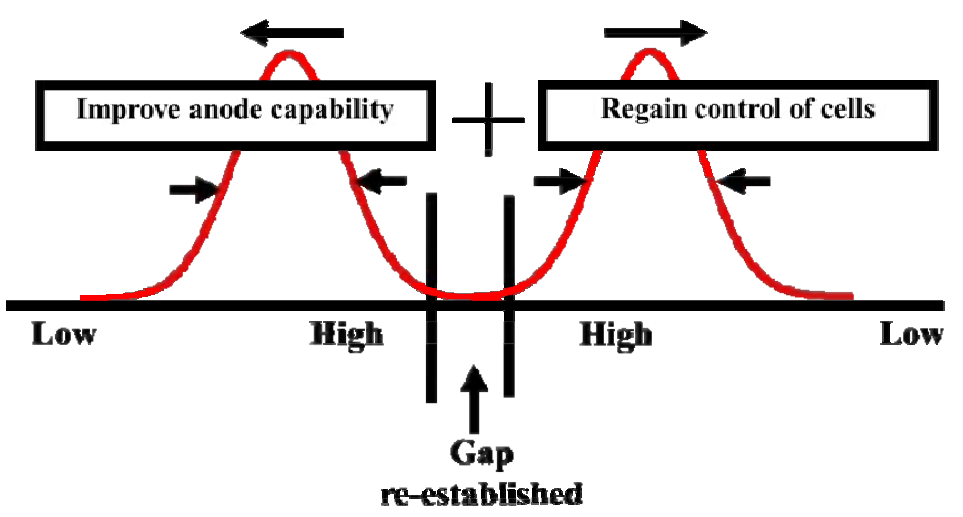

Fig. 42. Escaping from the anode and cell performance excursion; to do this it is necessary to reduce variation in anode quality, making them more capable and robust to the cell conditions, and at the same time work on the cells to address whatever the problem is, i.e. improving cover to counter airburn, skimming dust from cells, or regaining cell heat balance to reduce anode cracking

\section{Acknowledgements}

This paper is based on an accumulation of information from many sources that have not been individually referenced except where the diagrams of others have been used. While an effort has been made to recognise the contribution of others in the text, the Author would like to acknowledge the contribution made by the many people who have generated the information used in this paper.

\section{References}

[1] Dreyer, C., et. al., Light Metals 1997, 585, 591 p.

[2] Meier, M.W., et. al., Light Metals 1994, 685 p.

[3] Lee, E.S. et. al. Light Metals 1994, 535 p.

[4] Lee, E.S. et. al. Light Metals, 1994, 535 p. 